\title{
Dynamické modelování ložisek kaolinu na příkladu ložiska Jimlíkov-východ
}

\author{
Dynamic modelling of kaolin deposits on example of the Jimlíkov-East deposit
}

\author{
František Staněk', Jan Jelínek ${ }^{1,2}$, Radomír Grygar ${ }^{1} \Xi$, Jana Staňková1,3, \\ Marcela Jarošová ${ }^{3}$ \\ 'Institut čistých technologií těžby a užití energetických surovin, VŠB-Technická univerzita Ostrava, 17. listopadu 2172/15, \\ Ostrava, 70800 \\ 2 Česká geologická služba, Klárov 3, 11821 Praha 1 \\ ${ }^{3}$ Katedra matematiky FAST, VŠB-Technická univerzita Ostrava, 17. listopadu 2172/15, Ostrava, 70800
}

Key words:

3D modelling, EU commodities, kaolin deposit, visualization, estimates of reserves

$\triangle$

Editor:

Zdeněk Losos

Marek Slobodník

\begin{abstract}
This paper focuses on research within the project TE02000029 Competence Centre for Effective and Ecological Mining of Mineral Resources, granted by The Technology Agency of the Czech Republic, and, more specifically, on the research within its work package WP4 - Spatial modelling of mineral deposits. The focus of this work package is digital modelling of selected non-energetic raw materials, which belong to the critical commodities, as defined by the European Union. For modelling these deposits, suitable mathematical procedures, based on study and re-evaluation of archived data, are needed. One of the selected deposits is a kaolin deposit near the village Jimlikov near the city Karlovy Vary. In this paper, we show a step-by-step procedure for creation, visualization and evaluation of a 3D model of the deposit. This methodology, along with our recently developed software allows a user to create a variant of this dynamic model for the same or similar types of deposits, enables rapid updating of these models when adding or changing the input data on the basis of new mining exploration or when changing modelling parameters, such as using multiple variations interpolation parameters. Our methodology leads to a more advanced deposit evaluation, including adaptive estimates of the reserves based on the usability requirements we choose.
\end{abstract}

\section{Úvod}

Článek popisuje část řešení projektu TA ČR TE02000029 - Centrum kompetence efektivní a ekologické těžby nerostných surovin (CEEMIR), jehož hlavním cílem je revize zásob vybraných neenergetických surovin, které se řadí mezi strategické a kritické komodity EU (Mališ J. et al. 2014). Jednou z částí projektu je Work Package WP4 - Prostorové modelování ložisek nerostných surovin, který se zabývá převedením vybraných ložisek do digitálních modelů s pomocí vhodných matematických postupů na základě studia a přehodnocení dat $\mathrm{z}$ archivních materiálů. Část projektu WP4 se zabývala i modelováním ložisek kaolinu jako důležité suroviny v EU. Jedním z řešených ložisek bylo ložisko kaolinu Jimlíkov-východ, nacházející se v okolí obce Jimlíkov asi $5 \mathrm{~km}$ západně od Karlových Varů (obr. 1).

Dříve byly zásoby kaolinu stanovovány tak, jak bylo v té době obvyklé, staticky jednoduchými klasickými metodami (Hrzina et al. 1985; Jadrníček et al. 1960; Křelina et al. 1969; Neumann et al. 1992; Skopový et al. 1976; Tvrdý et al. 1986; Tvrdý et al. 2014) podle v té době schválených podmínek využitelnosti.

Ložisko kaolinu Jimlíkov-východ, vystupuje v oblasti sokolovské pánve, která je dílčí pánví systému oháreckého př́kopu. Vzniklo kaolinizací žul 


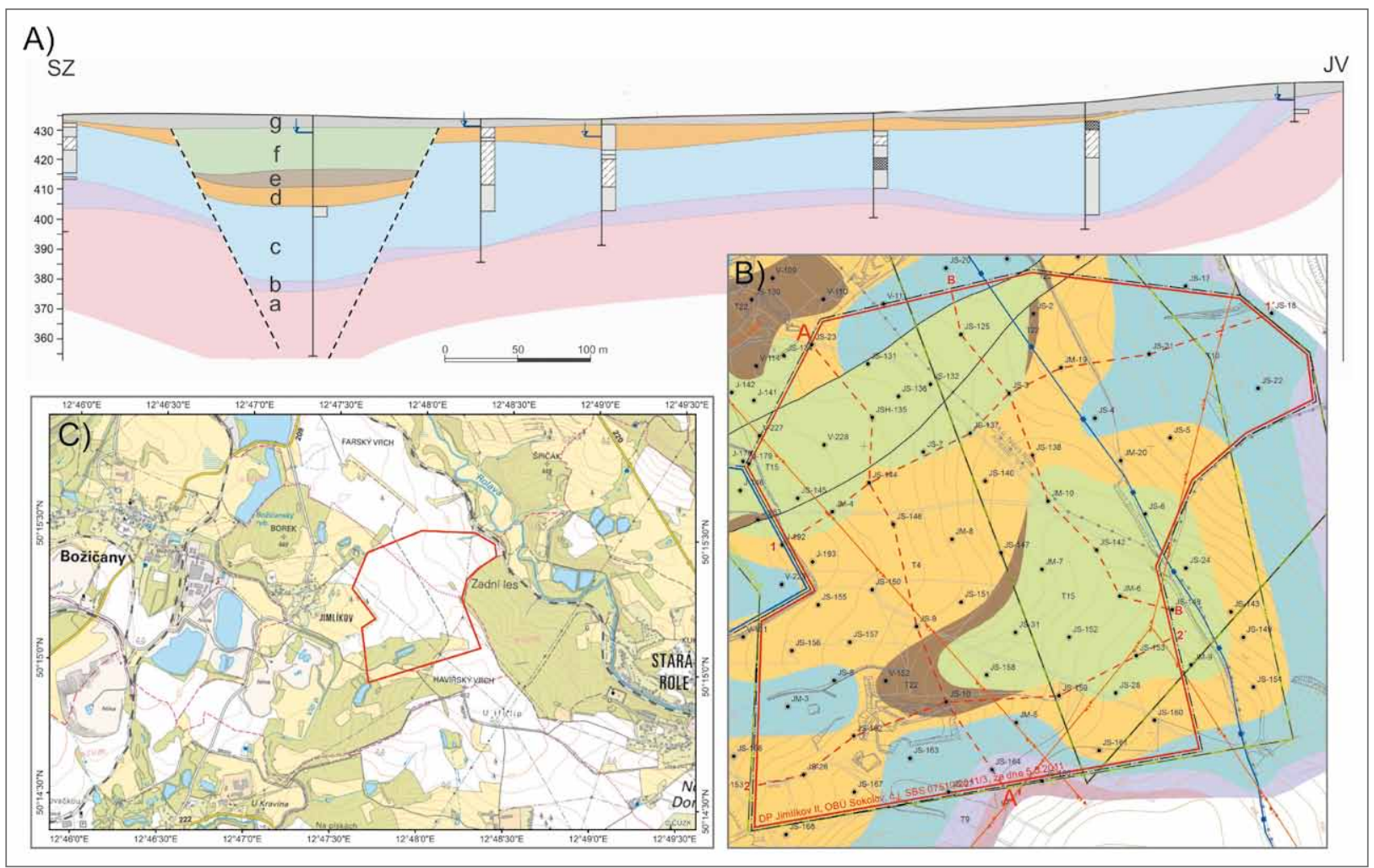

Obr. 1: Geologický řez (A) ložiskem kaolínu Jimlíkov, řez A-A' na schematické geologické mapě (B) a topografická mapa s pozicí ložiska (C) (viz červený polygon). Vysvětlivky k litologii společné pro mapu i řez: a - granit; b - kaolín s výplavem pod $15 \%$; c kaolín s výplavem nad $15 \%$; - kaolinické písky a pískovce (starosedelské souvrství); e - uhlí, uhelné jíly a písky slojového pásma Josef (novosedelské souvrství); f - tufy, tufity, bentonity a jíly (novosedelské souvrství); g - kvartér. Podle Tvrdý J. et al. (2014). Fig. 1: The geological profile (A) indicated as A-A' in the geological sketch map (B) of the Jimlíkov kaolin deposit and a topographic location map with a position of kaoline deposit indicated (red polygon). Explanatory notes: $a$ - granite; $b$ - kaoline with outwash under 15\%; c - kaolin with outwash over 15\%; d - kaolin sands and sandstones (Staré Sedlo member); e - coal, coal clays and sand of the Josef coal seams zone (Nové Sedlo member); f - tuffs, tuffites, bentonite a clays (Nové Sedlo member); g - Quaternary sediments. According to Tvrdý J. et al. (2014).

karlovarského masivu v období křída až paleogén. Jde o pozůstatky původní zvětralinové kůry, které byly uchovány před denudací. Karlovarský masiv, jenž je součástí rozsáhlého krušnohorského plutonu, tvoří krystalinické podloží ložiska.

V článku jsou popsány jednotlivé kroky tvorby a vizualizace 3D modelu tohoto ložiska od revize všech dostupných archivních materiálů a verifikace a korekce vstupních dat až po vizualizaci kategorií bloků zásob. Pomocí speciálně vytvořeného software je zajištěna kontrola vstupních dat, kompatibilita použitých programů a generování výstupů - odhadů zásob v textové formě a různých typů vizualizace ložiska ve $2 \mathrm{D}$ a ve $3 \mathrm{D}$. Tyto metodické postupy spolu s nově vyvinutým programovým vybavením umožňují vytvářet variantní modely ložisek kaolinu, umožňují i rychlé aktualizace modelů při doplnění nebo změně vstupních dat (případně i parametrů modelování). To vede k vytvoření aktivního, dynamického komplexního modelu ložiska kaolinu, do něhož je možno operativně doplňovat informace na základě prováděného těžebního průzkumu a následně okamžitě realizovat variantní odhady zásob podle zadaných podmínek využitelnosti.

V procesu modelování jsou využívány běžně dostupné programové prostředky: MS Excel, programy Surfer (Golden Software 2018a) a Voxler (Golden Software 2018b) firmy Golden Software a open-source program SGeMS (Remy et al. 2009). Pro tvorbu speciálních programových aplikací byly použity programovací jazyky: pro tvorbu maker v prostředí MS Office jazyk Visual Basic for Applications (VBA) a pro tvorbu samostatných programů jazyk Visual Basic.

\section{Metodický postup, algoritmy tvorby a výsledky vizualizace 3D modelu ložiska kaolinu}

V této kapitole jsou definovány jednotlivé kroky metodického postupu tvorby a vizualizace 3D modelu ložiska kaolinu na př́kladu ložiska Jimlíkov-východ. Jednotlivé kroky metodického postupu jsou realizovány tak, aby bylo možno při libovolné změně parametrů tyto kroky programově rychle přepočítat bez nutnosti zdlouhavých ručních postupů. Proto je také možné snadno provést modelování v několika variantách (například s použitím více variant parametrů gridování). Kroky metodického postupu:

1. Revize všech dostupných archivních materiálů.

Zdrojem údajů a informací pro kontrolu vstupních dat byly především dostupné archivní materiály o lokalitě z archivu Geofondu ČR z let 1960 až 1992 (Hrzina et al. 1985; Jadrníček et al. 1960; Křelina et al. 1969; Neumann 


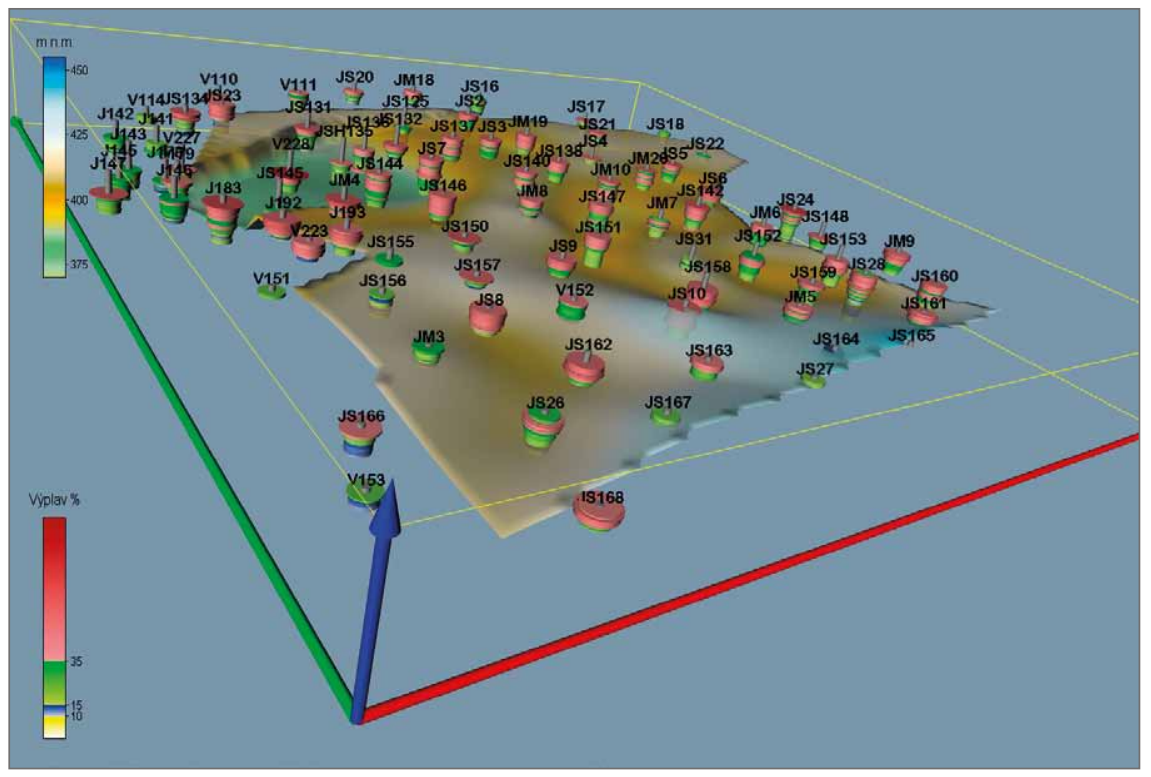

Obr. 2: Proporcionální zobrazení obsahu výplavu vzorků spolu s bází výskytu kaolinu. Fig. 2: Visualization of the kaolin outwash ("Výplav") proportion in the studied samples with the base occurrence of kaolin.

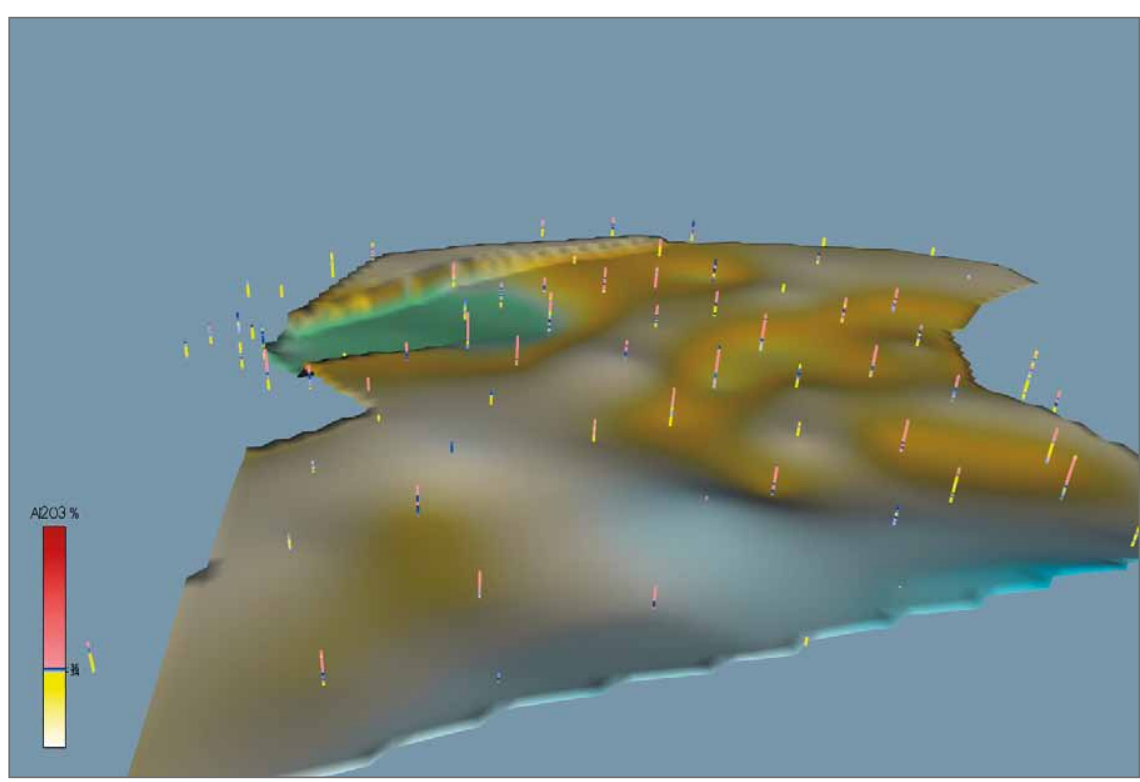

Obr. 3: Lokalizované údaje obsahu $\mathrm{Al}_{2} \mathrm{O}_{3}$ spolu s bází výskytu kaolinu.

Fig. 3: Localized $\mathrm{Al}_{2} \mathrm{O}_{3}$ content data together with the base occurrence of kaolin.

Tab. 1: Kategorizace keramických kaolinů na Karlovarsku.

Tab. 1: Categorization of ceramic kaolin in the Karlovy Vary region.

\begin{tabular}{|l|c|c|c|c|c|l|}
\hline $\begin{array}{l}\text { Kategorie } \\
\text { (tř́́da) }\end{array}$ & $\begin{array}{c}\text { Výplav } \\
{[\%]}\end{array}$ & $\begin{array}{c}\mathrm{Al}_{2} \mathbf{O}_{3} \\
{[\%]}\end{array}$ & $\begin{array}{c}\mathrm{Fe}_{2} \mathbf{O}_{3} \\
{[\%]}\end{array}$ & $\begin{array}{c}\mathrm{TiO}_{2} \\
{[\%]}\end{array}$ & $\begin{array}{c}\mathrm{Fe}_{2} \mathbf{O}_{3}+\mathrm{TiO}_{2} \\
{[\%]}\end{array}$ & Použití \\
\hline $\mathrm{K} 1$ & $>15$ & $>36$ & $<0,9$ & $<0,3$ & $<1,1$ & Kaolin pro výrobu porcelánu \\
\hline $\mathrm{K} 2$ & $>15$ & $>36$ & $<1,1$ & $<0,4$ & $<1,2$ & \\
\hline $\mathrm{K} 2 \mathrm{~A}$ & $>15$ & $34-36$ & - & $<0,5$ & $<1,2$ & \\
\hline $\mathrm{K} 51$ & $>10$ & $>36$ & - & $<0,3$ & $<1,0$ & \\
\hline $\mathrm{K} 2 \mathrm{~B}$ & $>15$ & $>36$ & - & $>0,4$ & $<1,6$ & Kaolin titaničitý \\
\hline $\mathrm{K} 3 \mathrm{~B}$ & $>15$ & $>36$ & - & $>0,5$ & $<2,0$ & \\
\hline $\mathrm{K} 4 \mathrm{~B}$ & $>15$ & $>34$ & - & $>0,5$ & $<2,5$ & \\
\hline $\mathrm{K} 3$ & $>15$ & $>34$ & - & $<0,5$ & $<1,6$ & Kaolin pro ostatní keramický průmysl \\
\hline $\mathrm{K} 4 \mathrm{~J}$ & $>35$ & $>34$ & - & - & $<5,0$ & \\
\hline $\mathrm{K} 4$ & $>15$ & - & - & - & $<3,0$ & \\
\hline $\mathrm{K} 5(\mathrm{NEG})$ & $>10$ & - & - & - & $>3,0$ & Nevhodný kaolin \\
\hline
\end{tabular}

et al. 1992; Skopový et al. 1976; Tvrdý et al. 1986) a závěrečná zpráva (Tvrdý et al. 2014).

2. Verifikace a korekce vstupních dat.

Verifikace vstupních dat byla prováděna konfrontací $\mathrm{s}$ archivními materiály a také s pomocí vizualizace (ve $2 \mathrm{D}$ a ve $3 \mathrm{D}$ ) a srovnáním $\mathrm{s}$ př́slušnými archivními horizontálními a vertikálními řezy (viz krok 1). Přitom byly zjištěny chyby, které byly způsobeny nejen překlepy souvisejícími s digitalizací archivních podkladů. Chybné údaje byly v maximální možné míre opraveny. Do výpočtu tak vstupují údaje z 85 průzkumných vrtů z let 1960 až 1990 a 1098 analyzovaných vzorků (obr. 2), u kterých byly na základě obsahů výplavu, $\mathrm{Al}_{2} \mathrm{O}_{3}, \mathrm{Fe}_{2} \mathrm{O}_{3}$ a $\mathrm{TiO}_{2}$ dopočteny kategorie (tř́ídy) zásob podle tabulky 1 .

3. Výpočet a vizualizace prostorové lokalizace vstupních dat.

Opravené a doplněné vstupní údaje (geometrické parametry průzkumných děl a vzorky s obsahy technologických parametrů) se s pomocí makra rozdělí po $10 \mathrm{~cm}$ úsecích na jednotného nositele (celkem 21209 ) a prostorově se lokalizují ve středu každého úseku. Tyto údaje jsou vstupem pro další zpracování: pro výběr dat pro tvorbu horizontálních a vertikálních řezů, pro statistické analýzy, gridování, vizualizaci ve $2 \mathrm{D}$ a $3 \mathrm{D}$ aj. Jako příklad jsou na obrázku 3 zobrazeny lokalizované údaje obsahu $\mathrm{Al}_{2} \mathrm{O}_{3}$.

4. Statistické zpracování technologických parametrů.

Základní statistické zpracování technologických parametrů je prováděno v prostředí SGeMS (Remy et al. 2009). Ukázka výstupů je na obrázku 4 - histogram četností výplavu a regresní závislost výplavu na hloubce. 


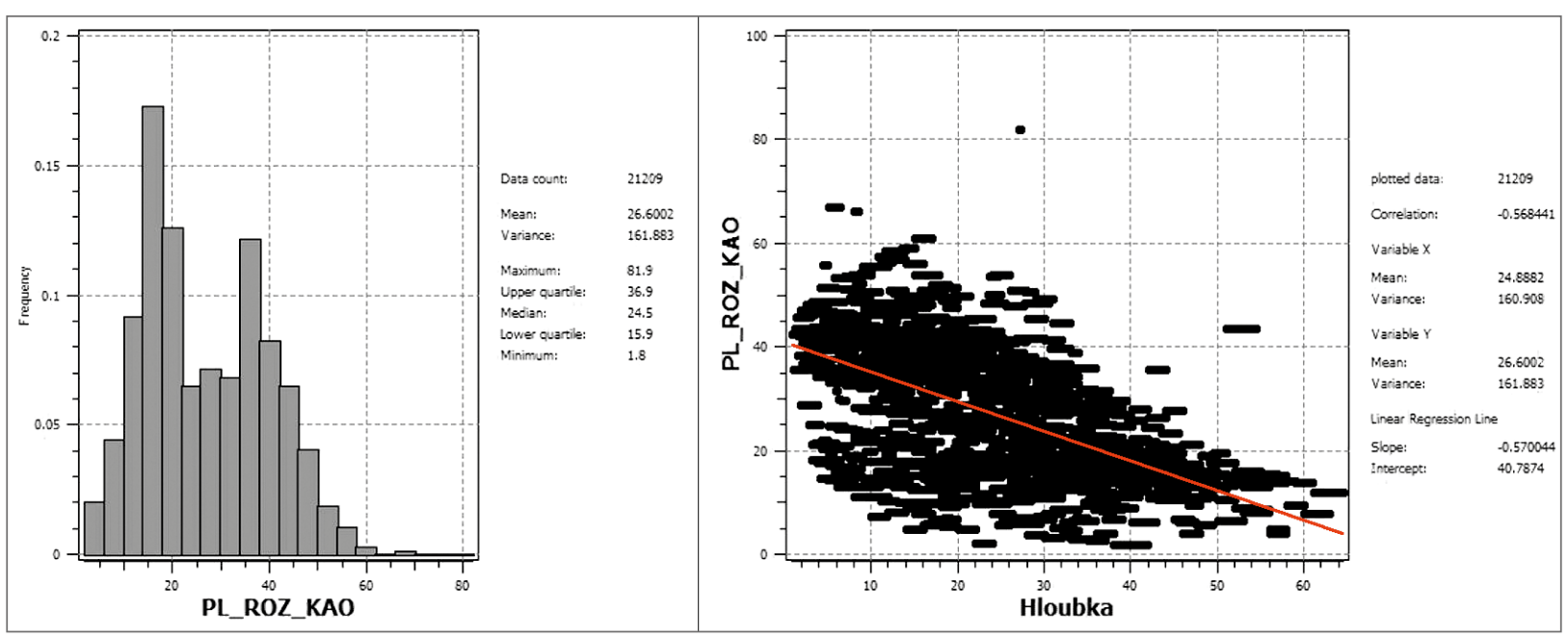

Obr. 4: Histogram četností parametru výplav (vlevo) a regresní závislost výplavu na hloubce (vpravo).

Fig. 4: Histogram of frequency of the kaolin outwash = PL_ROZ_KAO (left) and regression dependence of the kaolin outwash on the depth = Hloubka (right).

5. Modelování báze a stropu výskytu kaolinu a celkové litologie ložiska.

Výsledkem práce geologů bylo vytvoření $2 \mathrm{D}$ gridů osmi geologických vrstev od krystalinického podloží až po povrch. Na jejich základě byly vytvořeny gridy báze (obr. 3) a stropu výskytu kaolinu, kterými je omezen 3D model ložiska. $\mathrm{V}$ průběhu těžby je nezbytné pravidelně aktualizovat grid stropu výskytu kaolinu.

6. Zobrazení vstupních dat ložiska kaolinu ve 3D $\mathrm{v}$ prostředí Voxler, vytvoření 3D gridů obsahů technologických parametrů a export $2 \mathrm{D}$ gridů $\mathrm{v}$ jednotlivých horizontech ve formátu Surfer (program Kaolin_A).

Program Kaolin_A vygeneruje 3D gridy jednotlivých technologických parametrů podle zadaných parametrů anizotropie, geometrie gridu a výběru vzorků pro interpolaci (tyto parametry lze měnit a vytvářet tak varianty modelů ložiska) a exportuje je také ve formě série horizontálních $2 \mathrm{D}$ gridů pro další zpracování. Každý bod 3D gridu pak představuje blok zásob kaolinu zadané velikosti (např́klad $10 \times 10 \times 1 \mathrm{~m}$ ). Program Kaolin_A vygeneruje v prostředí Voxleru i různé způsoby zobrazení aktualizovaných dat (viz krok 3) a 3D gridů jednotlivých technologických parametrů. $\mathrm{Na}$ obrázku 5 je ukázka jednoho z výstupů programu Kaolin_A - vizualizace obsahu $\mathrm{Al}_{2} \mathrm{O}_{3}$.

7. Kategorizace bloků zásob ve $2 \mathrm{D}$ gridech jednotlivých horizontů na základě gridů technologických parametrů exportovaných programem Kaolin_A a zadaných parametrů kategorií zásob, převedení $2 \mathrm{D}$ gridů kategorií bloků zásob do $3 \mathrm{D}$ gridu a odhad zásob ložiska (program Kaolin_Viz).
První z modulů programu Kaolin_Viz provede kategorizaci bloků zásob na základě gridů technologických parametrů exportovaných programem Kaolin_A (viz krok 6) a zadaných parametrů kategorií zásob (tab. 1). Kódy kategorií bloků zásob jsou pro další zpracování uchovány jednak ve formě série horizontálních $2 \mathrm{D}$ gridů, jednak ve formě $3 \mathrm{D}$ gridu. Tento modul současně provádí odhad zásob kaolinu ložiska v textové formě.

8. Vizualizace horizontálních řezů ve $2 \mathrm{D}$ v prostředí Surfer (program Kaolin_Viz).

Druhý z modulů programu Kaolin_Viz postupně generuje a zobrazuje uživatelem zadané horizontální řezy bloků zásob ve $2 \mathrm{D} v$ prostředí Surfer v zadaném měřítku. Na obrázku 6 je vizualizace jednoho ze série takto vygenerovaných horizontálních řezů v prostředí Surfer. Zapínáním, případně vypínáním objektů v levém okně (obr. 6) lze zobrazit:

- Kategorie bloků zásob kaolinu řezu (objekt Kategorie).

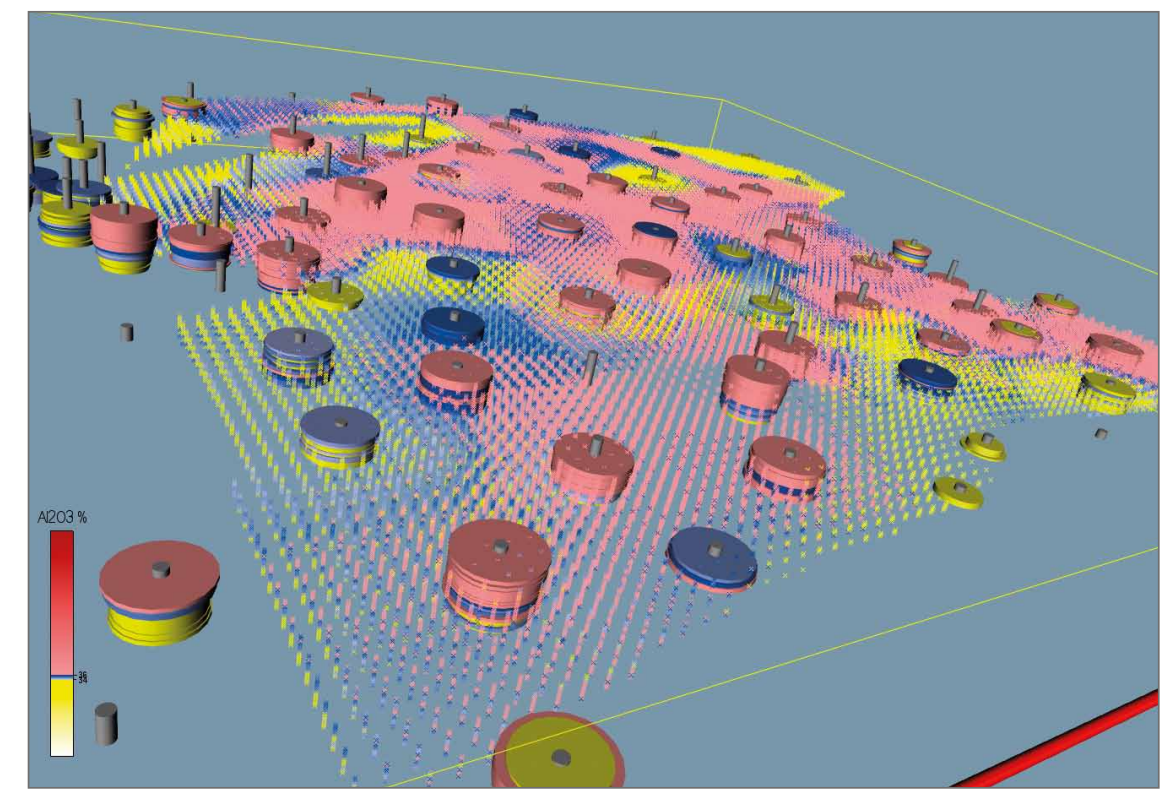

Obr. 5: 3D vizualizace obsahu $\mathrm{Al}_{2} \mathrm{O}_{3}$ - zobrazení 3D gridu pomocí ScatterPlot.

Fig. 5: 3D visualization of the $\mathrm{Al}_{2} \mathrm{O}_{3}$ content - depicting the $3 \mathrm{D}$ grid via ScatterPlot. 
- Obsahy Výplavu (objekt Vyplav), $\mathrm{Al}_{2} \mathrm{O}_{3}$ (objekt $\mathrm{Al}_{2} \mathrm{O}_{3}$ ), $\mathrm{Fe}_{2} \mathrm{O}_{3}$ (objekt $\mathrm{Fe}_{2} \mathrm{O}_{3}$ ), $\mathrm{TiO}_{2}\left(\right.$ objekt $\mathrm{TiO}_{2}$ ) a $\mathrm{Fe}_{2} \mathrm{O}_{3}+\mathrm{TiO}_{2}$ (objekt $\mathrm{Fe}_{2} \mathrm{O}_{3}+\mathrm{TiO}_{2}$ ) bloků řezu.

- Color Scale Kategorií bloků zásob kaolinu (objekt Color Scale Kategorie), obsahu Výplavu (objekt Color Scale Vyplav), obsahu $\mathrm{Al}_{2} \mathrm{O}_{3}$ (objekt Color Scale $\mathrm{Al}_{2} \mathrm{O}_{3}$ ), obsahu $\mathrm{Fe}_{2} \mathrm{O}_{3}$ (objekt Color Scale $\mathrm{Fe}_{2} \mathrm{O}_{3}$ ), obsahu TiO (objekt Color Scale $\mathrm{TiO}_{2}$ ) a obsahu $\mathrm{Fe}_{2} \mathrm{O}_{3}+\mathrm{TiO}_{2}$ (objekt Color Scale $\mathrm{Fe}_{2} \mathrm{O}_{3}+\mathrm{TiO}_{2}$ ) bloků řezu.

- Pozice a názvy vrtů v řezu (objekt Vrty).

- Hodnoty údajů o jednotlivých blocích zásob (objekt Bloky).

- Obvod ložiska (objekt Obvod ložiska).

- Jednotlivé osy souřadného systému (Objekty Right Axis, ...).

Po nastavení měřítka objektu Map, prrípadně po dalších formálních doplněních, lze každý takový řez přímo tisknout na vhodné výstupní zařízení.

9. Vizualizace sítě vertikálních řezů ve $2 \mathrm{D}$ v prostředí Surfer (program Kaolin_Viz).

Třetí z modulů programu Kaolin_Viz postupně generuje a zobrazuje uživatelem zadanou sít vertikálních řezů XZ a YZ bloků zásob ve $2 \mathrm{D} v$ prostředí Surfer v zadaném měřítku. $\mathrm{Na}$ obrázku 7 je vizualizace jednoho ze série takto vygenerovaných vertikálních řezů v prostředí Surfer. Zapínáním, př́ípadně vypínáním objektů v levém okně (obr. 7) lze navíc zobrazit:

- Pozice, názvy a vzdálenost od řezu vrtů vybraných do řezu (objekt Vrty_vzdálenost).

- Hodnoty údajů o jednotlivých vzorcích ve vrtech (objekt Vrty_Samples).

- Průběhy vrtů vybraných do řezu (objekt Průběhy vrtů).

- Úseky do řezu vybraných vrtů se vzorky kategorií K1, K2, ..., NEG (objekty Base_ K1, Base_K2, ..., Base_NEG).

- Průběh báze (objekt Báze kaolinu) a stropu (objekt Strop kaolinu) výskytu kaolinu $\mathrm{v}$ řezu.
Po nastavení měřítka objektu Map, případně po dalších formálních doplněních, lze každý takový řez přímo tisknout na vhodné výstupní zařízení.

10. Vizualizace kategorií bloků zásob ve $3 \mathrm{D}$ v prostředí Voxler (program Kaolin_Viz).

Čtvrtý z modulů programu Kaolin_Viz realizuje různé způsoby vizualizace kategorií bloků zásob ve $3 \mathrm{D}$ v prostředí Voxler. Na obrázku 8 je ukázka jednoho ze způsobů vizualizace, v levé části je okno se strukturou

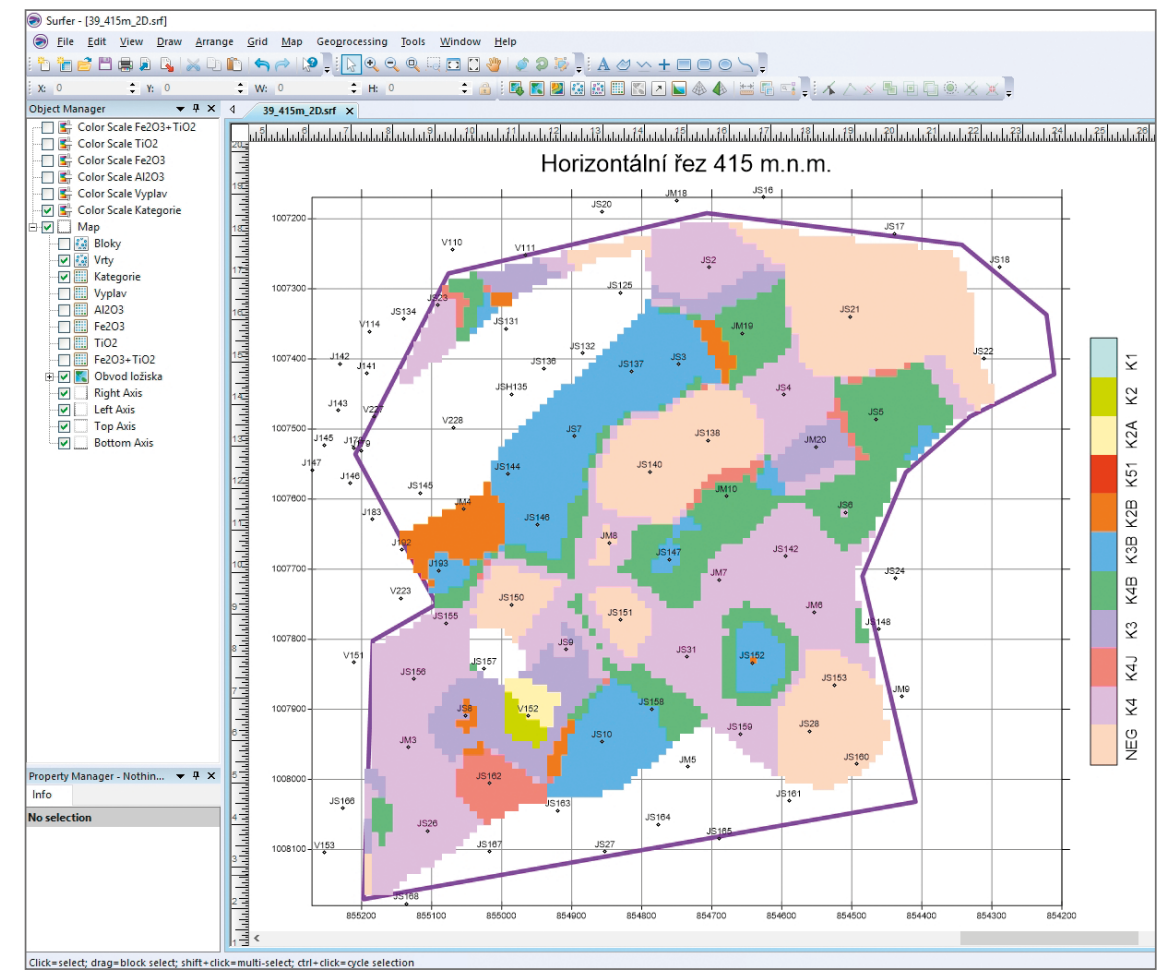

Obr. 6: Vizualizace horizontálního řezu $415 \mathrm{~m}$. n. m. v prostředí Surferu.

Fig. 6: Visualization of a horizontal section $415 \mathrm{~m}$ a. s. l. in the Surfer environment.

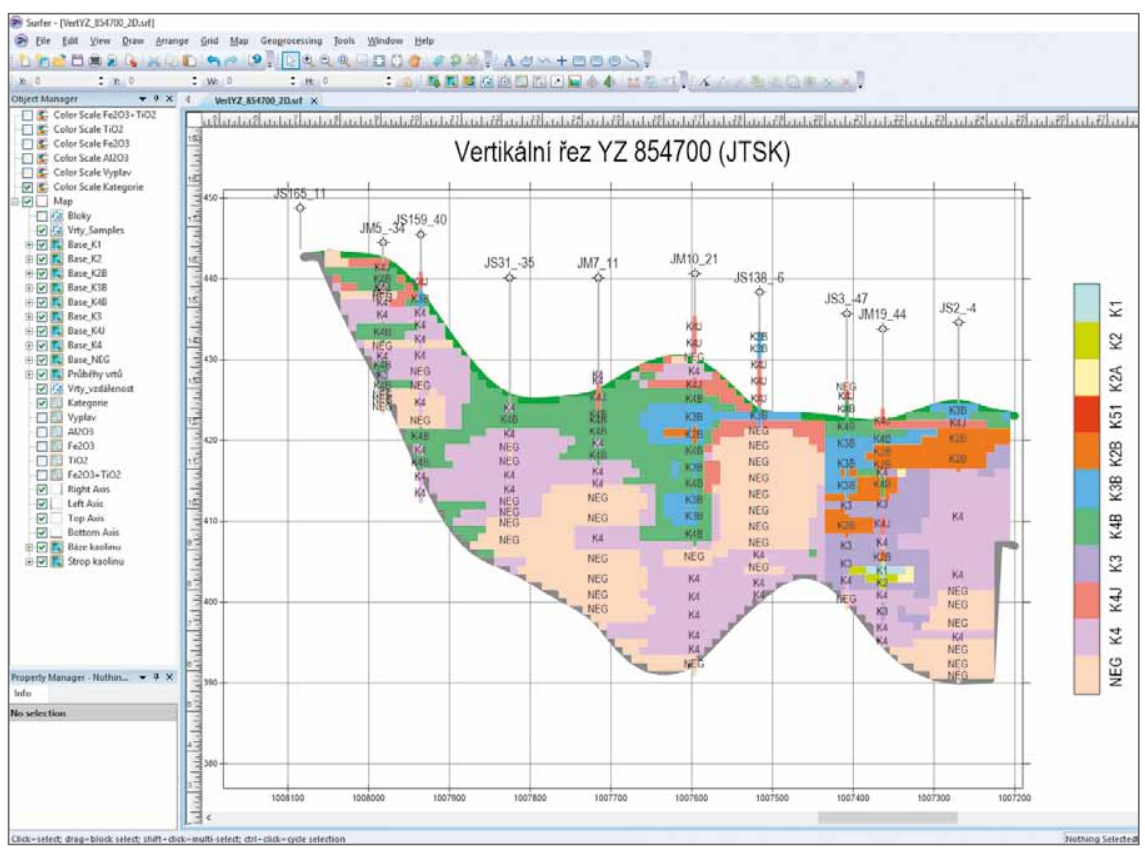

Obr. 7: Vizualizace vertikálního řezu YZ 854700 v prostředí Surferu.

Fig. 7: Visualization of the vertical section YZ 854700 in the Surfer environment. 


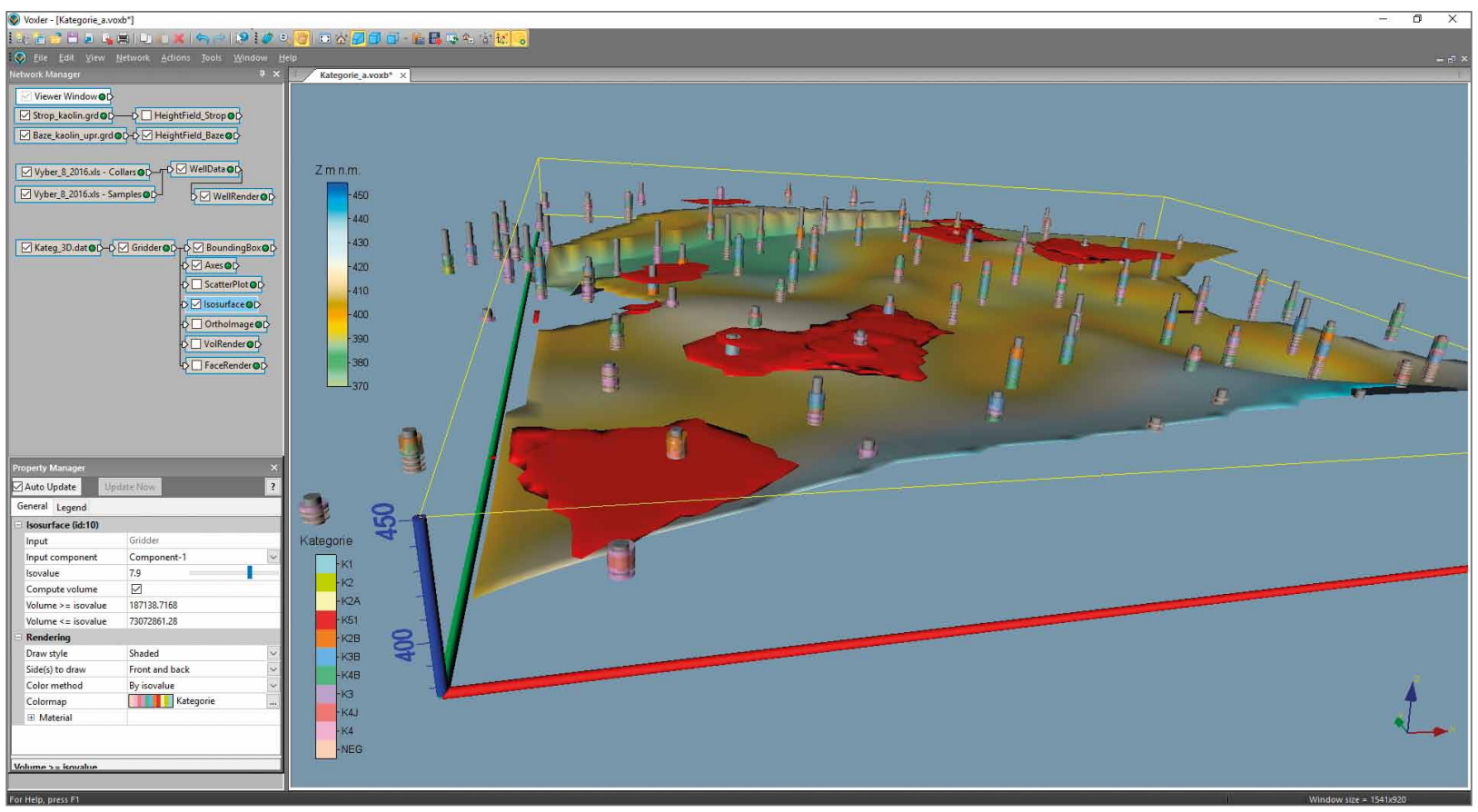

Obr. 8: 3D vizualizace kategorií bloků zásob - zobrazení obálky těles kategorií K1, K2, K2A a K51 (Isosurface) a báze výskytu kaolinu.

Fig. 8: 3D visualization of categories of blocks of reserves - display of an envelope of the solids of the K1, K2, K2A and K51 categories (Isosurface) and base for the occurrence of kaolin.

jednotlivých modulů Voxleru vygenerovaných programem Kaolin_Viz.

11. Případné doplnění vstupních údajů na základě prováděného těžebního průzkumu a přechod ke kroku 6.

$\mathrm{V}$ prrípadě doplnění vstupních údajů na základě prováděného těžebního průzkumu je nezbytné doplněné údaje zpracovat tak, jak bylo popsáno v krocích 2 až 4 . Při probíhající těžbě je také nezbytné zaktualizovat grid stropu výskytu kaolinu (viz krok 5). Poté je vše připraveno pro aktualizaci modelu a jeho vizualizaci postupem popsaným v krocích 6 až 10 .

\section{Diskuze}

Poslední dostupný výpočet zásob popisované lokality byl proveden metodou geologických bloků (Tvrdý et al. 2014). Při její aplikaci je objem zásob roven součinu plochy bloku a průměrné mocnosti suroviny. Plocha bloků se, jak známo, určuje z mapového podkladu na základě ložiskového hodnocení archivních vrtů (identifikace bilančních, nebilančních a negativních vrtů), přičemž pravidlo pro interpolaci bylo stanoveno na $1 / 3$ vzdálenosti mezi bilančním a negativním vrtem pro bilanční zásoby, $1 / 2$ vzdálenosti mezi bilančním a nebilančním vrtem pro bilanční zásoby a $1 \frac{1}{2}$ vzdálenosti mezi nebilančním a negativním vrtem pro nebilanční zásoby.

Uplatnění našeho, v článku popisovaného metodického postupu, a především nově vyvinutého softwaru je novátorské hlavně v tom, že modelování je (na rozdíl od dříve používaných statických metod) realizováno dynamicky, kdykoliv tak lze operativně doplnit vstupní informace na základě prováděného těžebního průzkumu a v reálném čase provést variantní odhady zásob podle zadaných podmínek využitelnosti. Okamžitě se také vygenerují grafické výstupy - vizualizace obsahů technologických parametrů a kategorií bloků zásob ložiska ve $2 \mathrm{D}$ v nadstavbě prostředí programu Surfer (série horizontálních a vertikálních řezů v uživatelem zadané hustotě) a ve $3 \mathrm{D}$ v prostředí programu Voxler.

V procesu realizace modelování ložiska kaolinu Jimlíkov - východ byly velmi pracné opravy zjištěných chyb $\mathrm{z}$ archivních vstupních dat, tak jak bylo popsáno v krocích 1 a 2 metodického postupu. Tento proces se ale provedl pouze jednou a při opakování výpočtu v prrípadě doplnění nových vstupních dat už je tento problém eliminován.

\section{Závěr}

Předkládaná metodika modelování ložiska kaolinu je unikátní v tom, že specifikuje jednotlivé kroky metodického postupu od pořízení potřebných vstupních údajů $\mathrm{z}$ archivní dokumentace, přes uplatnění moderních algoritmů tvorby variantních 3D modelů ložiska, až po odhady zásob a vizualizaci kategorií bloků zásob.

Pomocí speciálně vytvořeného programového vybavení je zajištěna kontrola vstupních dat, kompatibilita použitých programů (MS Excel, Surfer, Voxler, SGeMS) a je také realizováno automatické generování výstupů různých typů vizualizace ložiska ve $2 \mathrm{D}$ a ve $3 \mathrm{D}$.

Tato metodika spolu s nově vyvinutým programovým vybavením umožňuje vytvářet variantní modely ložiska kaolinu, umožňuje také rychlé aktualizace těchto modelů při doplnění nebo změně vstupních dat (případně i parametrů modelování - např́íklad použití více variant parametrů interpolace). Uplatnění popsaných metodických postupů vede $\mathrm{k}$ vytvoření aktivního, dynamického a komplexního modelu ložiska kaolinu, do něhož lze operativně doplňovat informace na základě prováděného 
těžebního průzkumu včetně realizace variantních odhadů zásob podle zadaných podmínek využitelnosti.
Poděkování

Děkujeme editorům a recenzentům za kritické pročtení rukopisu a pripomínky, které vedly ke zkvalitnèní výsledného textu. Článek byl pripraven za podpory projektu TAČR TE02000029 - CEEMIR (Centrum kompetence efektivní a ekologické těžby nerostných surovin).

\section{Literatura}

Hrzina, P. et al. (1985). Jimlíkov II. - MS, závěrečná zpráva. Geoindustria. Praha.

Jadrníček, P. et al. (1960). Božičany. - MS, závěrečná zpráva. Nerudný průzkum. Praha.

Křelina, B. et al. (1969). Jimlíkov. - MS, závěrečná zpráva. Geoindustria. Praha.

Neumann, J. et al. (1992). Jimlíkov-sever II. - MS, závěrečná zpráva. GMS. Praha.

Remy, N., Boucher, A., Wu, J. (2009). Applied geostatistics with SGeMS: a user's guide. -Cambridge University Press, New York, $264 \mathrm{~s}$.

Skopový, J. et al. (1976). Božičansko sever. - MS, závěrečná zpráva. Geoindustria. Praha.

Tvrdý, J. et al. (1986). Jimlíkov-sever. - MS, závěrečná zpráva. Geoindustria. Praha.

Tvrdý, J. et al. (2014). Závěrečná zpráva Jimlíkov-východ (přehodnocení ložiska keramického kaolinu a cihlářské suroviny Jimlíkov-sever v dobývacím prostoru Jimlíkov II). - MS, závěrečná zpráva. GET s.r.o. Praha.

Mališ, J. et al. (2014). Centrum kompetence efektivní a ekologické těžby nerostných surovin. - Dostupné na: https://www.hgf.vsb. cz/511/cs/Projekty/CEEMIR/, 21.2.2019.

Golden Software (2018a). Surfer. Explore the depths of your data. - Dostupné na: http://www.goldensoftware.com/products/ surfer/features, 21.2.2019.

Golden Software (2018b). Voxler. Power forward into 3D visualization. - Dostupné na: https://www.goldensoftware.com/products/ voxler/features, 21.2.2019. 